\title{
Complex Agricultural Risk Management System: a new information system supporting the claim adjustment process in the Hungarian agriculture
}

\author{
Gábor Kemény ${ }^{1}$, László Rieger ${ }^{2}$
}

\section{N F O \\ Received 16 Jun. 2013 \\ Accepted 27 Jun. 2014 \\ Available on-line 10 July. 2014 \\ Responsible Editor: K. Rajkai}

\section{Keywords:}

Meteorological risk, claim

adjustment, .information

system, national damage

mitigation, insurance

\begin{abstract}
$\underline{\text { A B S T R A C T }}$
On annual basis the magnitude of weather-related risks of the Hungarian farmers approaches the 100 billion HUF. It is about 5 percent of the 2200 billion HUF annual gross output value of the Hungarian agriculture. It is a continuous tendency that climate factors are more and more significantly influencing the agricultural crop production. Therefore, reducing the weather risks is an important objective of the Hungarian agricultural administration. For this the agricultural administration is forming riskmanagement groups for producers by strengthening the liability for their decisions, and providing more significant support by the agricultural administration. This new system is based on two pillars: the first pillar is an extended mitigation system, and the second one is a business-based state-sponsored insurance system. First we describe the agricultural risk management in general, then the "paper-based" coordinated mitigation system launched in 2012, finally the integrated mitigation system being under development. Our study reveals in recent year agricultural risk management which is going through important changes, in particular a significant reduction in its administrative burden for farmers and public administration. The other improvement is the accuracy of agricultural meteorological risk evaluation based on agricultural risk database for public decisionmaking.
\end{abstract}

\section{Introduction}

The agriculture faces a lot of meteorological risks, like drought, hail, frost, flood and inland water. These risks cause losses in a volume of 100 billion HUF yearly on average for the Hungarian farmers (Kemény et al., 2011). The probability of the adverse climatic events will increase due to climate change, so the importance of the risk management tools in the agriculture is growing (de Bruin et al., 2009).

As a response to the challenge of climate change the expansion of the portfolio of risk management tools can be observed not only in the OECD countries (OECD, 2009; Székely and Pálinkás, 2009), but in the developing countries as well (Smith and Glauber, 2012). The development is fundamentally based on simple and complex insurance policies and on systems providing income stability. Canada is the best example for this (Antón et al. 2011). However, it is clear that if a security system is not adequate enough, and there are no detailed accounts of the insurance system performance monitoring, it does not reach the objective, and becomes a costly subsidy for the participants (Mahul and Stutley, 2010). If a risk management system wants to avoid the contra-selection and the shrinkage of the number of members of the risk community it is necessary to build an information technology system with which it is possible to follow the cash flow not only at national or county level, but at the level of small regions, even at parcel-level (Kemény et al., 2013).

The aim of this paper is to describe the situation and the development of the Hungarian agricultural risk management system and the major innovations of the planned new information system, which

\footnotetext{
${ }^{1}$ Gábor Kemény

Research Institute of Agricultural Economics, Hungary

kemeny.gabor@aki.gov.hu

2 László Rieger

Research Institute of Agricultural Economics, Hungary

rieger.laszlo@aki.gov.hu
} 
assists the operation of the risk management scheme and establishes the creation of a database that satisfies the above mentioned expectations and ensures the growth of the insurance risk community in Hungary.

\section{The major elements of the Hungarian agricultural risk management}

Before 2012 the Hungarian agricultural producers could handle the weather risk in two ways: using commercial contracts offered by market insurance companies, and/or using the state-organized National Damage Mitigation Fund (NDMF).

The commercial Hungarian agricultural meteorological risk management market consists of 3-4 insurance companies.

At that time the next four state organizations worked together to operate the NDMF:

- the Ministry of Rural Development (MRD) responsible for the general management of the Hungarian Agricultural Risk Management System (supervision, analysis and planning);

- the National Food Chain Safety Office (NFCSO), as responsible for the general damage assessment;

- the Regional Government Offices (RGO) as an executive member for the field damage assessment, serving NFCSO general activity;

- the Agricultural and Rural Development Agency (ARDA), as responsible for operation of NDMF, the management of compensation contributions and the determination of compensations, payment and accounting of compensation or/and insurance subsidies.

Technical support from other professional organizations, like the General Directorate of Water Management (GDWM), the Hungarian Meteorological Service (HMS), the Institute of Geodesy, Cartography and Remote Sensing (IGCRS) and the Research Institute of Agricultural Economic (RIAE) contributed to this activity only in special cases.

It can be identified that the annual average loss caused by meteorological risks amounted 100 billion HUF, which is ten times more than the volume of the premiums paid to the farmers and of the sum of the NDMF (Figure 1). So only 10 percent of the produced crop was insured or covered by the mitigation fund.

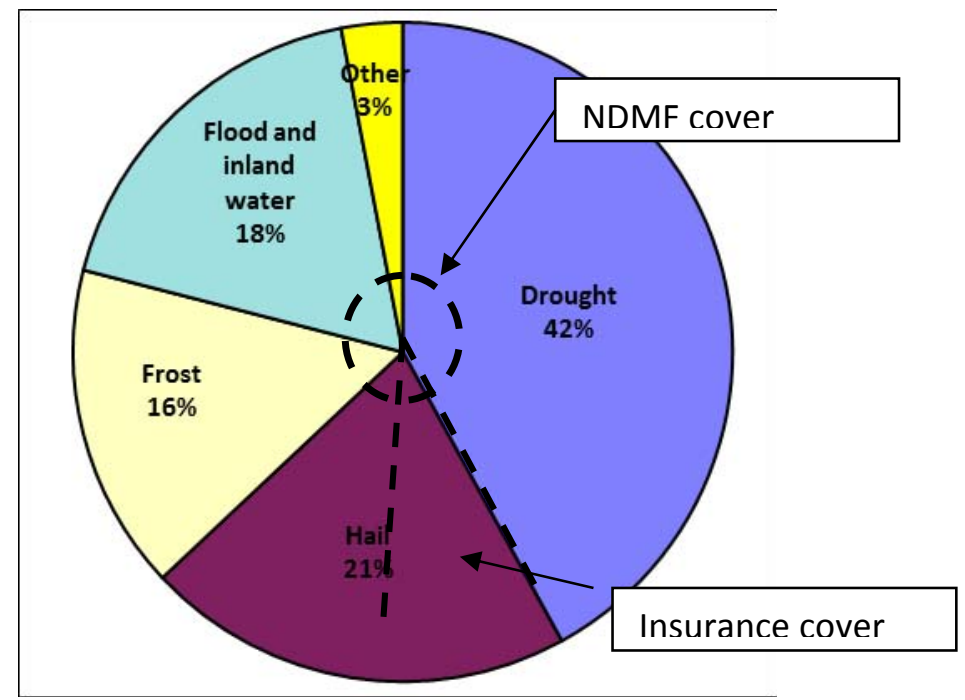

Figure 1. The differences in coverage between the Market Insurance and the National Damage Mitigation System in Hungary Source: MABISZ, VM

The market insurance and the NDMF system used different operational principles. NDMF provided protection against all kinds of risks (such as drought, hail, frost, flood and inland water, storm), but it 
did not guarantee to cover all the losses since the fund always had to be balanced. So when unexpected, major damages occurred, the fund could only reimburse pro rata, in some cases only $10 \%$ of the damage could be reimbursed, which did not provide significant assistance to the farmers.

In contrast, insurance companies claimed that they would guarantee to reimburse 90 percent of the damages listed in the contract in any circumstances. Thus the agricultural insurance activity often became unprofitable in a given year. Although this meant valuable assistance for the farmers, due to the indemnification obligations, insurers could not undertake the insurance of risks of great damages, such as drought, flood and inland water.

Therefore a mismatch formed between the distribution of losses caused by risks and the distribution covered risks. The insurance policies covered only the damages caused by hail, but the most important risk was the drought (Figure 2).

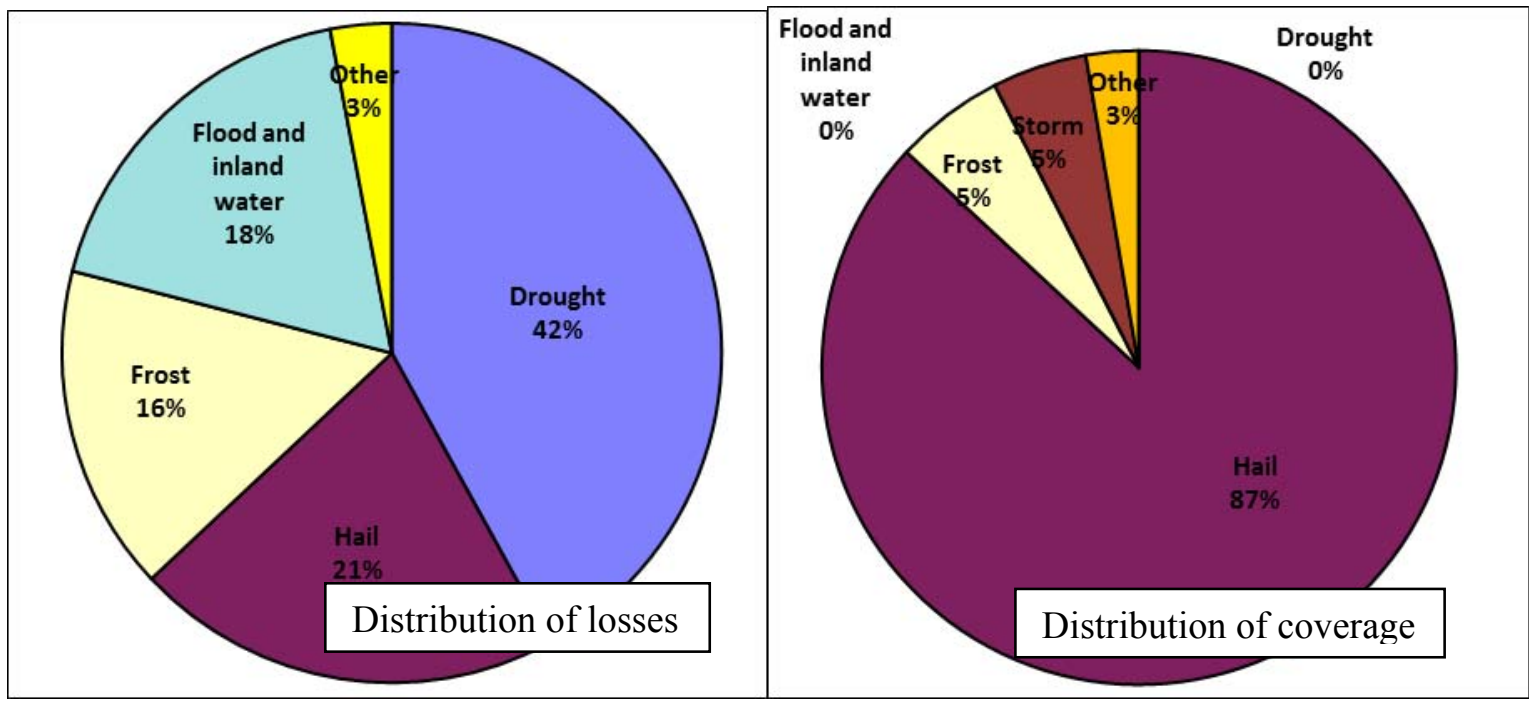

Figure 2. Distribution of losses and coverage of risks by insurance companies in Hungary Source: MABISZ, MVH

The data can be interpreted as the underdevelopment of the Hungarian risk management market, so the farmers' income was not enough for purchasing better insurances, and the insurance companies offered mainly hail insurance policies because the other climatic events have a systemic nature which cannot be covered by insurance (MABISZ, 2013).

Because of the unsynchronized operation of the NDMF and the market insurances, the farmers who had covered their risk by buying insurance did not receive any benefit from the NDMF. The risk definitions used by the mitigation system and the insurance policies were also different (MVH, 2013).

All producers could join the compensation scheme voluntarily. The producer had to send the entrance application to ARDA and at the same time had to pay a fee per hectare, which was called payment of mitigation contribution. The damage notification and the damage claim notification had to be reported in person or by mail to the NFCSO or to the RGO. After the reception of the damage notification of losses an official controller visited the site and assessed the actual damage. Based on the site control an official certificate was issued regarding the actual damage. At the end of the year all participants of the mitigation system could submit by mail these official certificates along with damage compensation claim form to NFCSO. The yearly damage compensation claim was a selfassessment of loss of the producers, and it was supervised and checked by the officers of NFCSO. After the official control an additional official certificate was issued about the audited compensation request which was forwarded to ARDA. At ARDA the whole file was checked again, the yield-loss calculations were recalculated, and it was verified that the producer was a registered participant of the mitigation system and that he paid his fees. This was followed by an aggregation, which had to be submitted to MRD. Then in MRD it was decided what percentage of the claim would be paid to the producers, depending on the overall claims submitted and on the amount of the collected mitigation 
fees. Then ARDA sent the decisions to the producers about the rate of compensation they might expect.

To sum up, the operation of the system was based on overlapping manual administration, the state mitigation system created the duplication of work at ARDA and at NFCSO, it was based on paper administration, the damage assessment was handled by human spot checks, and its operation was not coordinated efficiently by the commercial market insurance policies. As a result this system could be improved in several ways.

\section{The items and the operation of the Coordinated Risk Management System after 2012}

The reform introduced in 2012 linked the state mitigation and the market insurance together. The new rules were implemented in the Agricultural Risk Management Act.

The first step was making the NDMF (first pillar) membership compulsory for the farmers above 5 or 10 hectares, so the risk community increased to 75000 members. The size of the mitigation fund has doubled, the mitigation payments of the fund have been linked to the actual meteorological or remote sensing indices characterizing adverse climatic events (Figure 3).

The second pillar is an insurance premium subsidy, depending on the type of covered risk: the multi-peril insurances named " $\mathrm{A}$ " covering the drought and frost. The most important risks have priority and are covered by a guaranteed $65 \%$ premium subsidy, the one-risk insurances named "B" and "C" are subsidised from remained sources only (Figure 4).

The two pillars are linked by the unified risk definitions, by the minimal request of meteorological indices on the site of crop losses, and by the disadvantage of not insured farmers in the first pillar by a halved mitigation payment. Due to this and the favorable weather conditions observed from 2011, the producer compensation claims fell significantly.

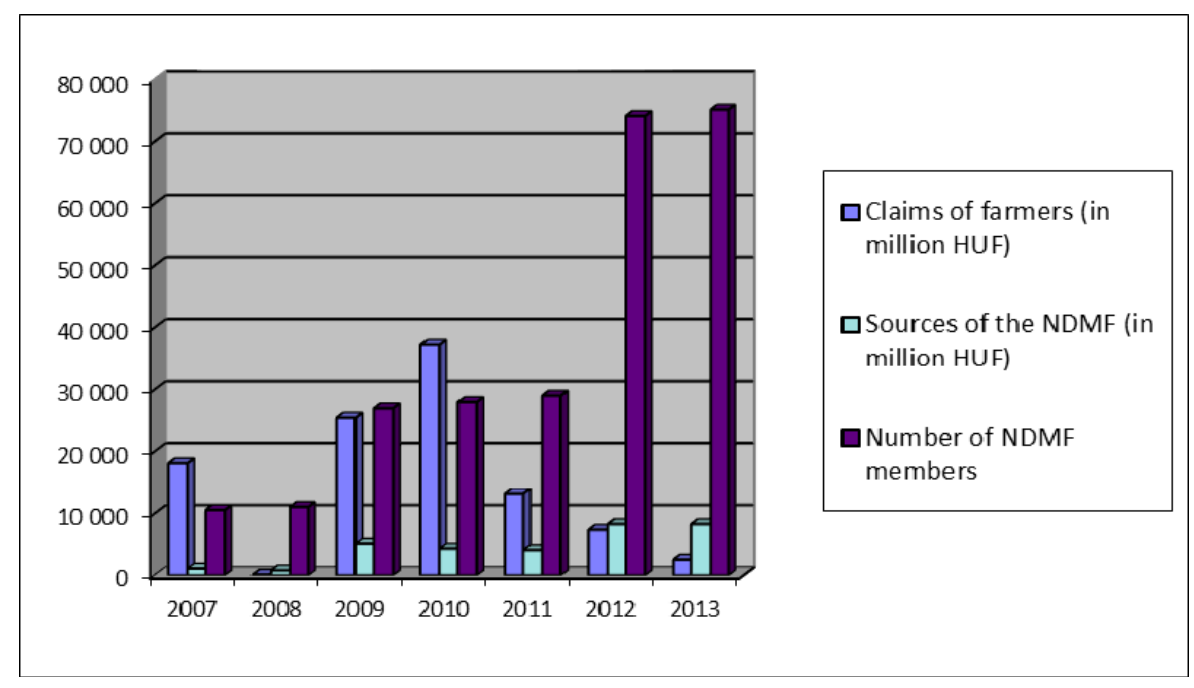

Figure 3. Changes in the claimed damages, the sources of the NDMF and the number of members of the first pillar of the risk management system between 2007 and 2013, Source: MVH 


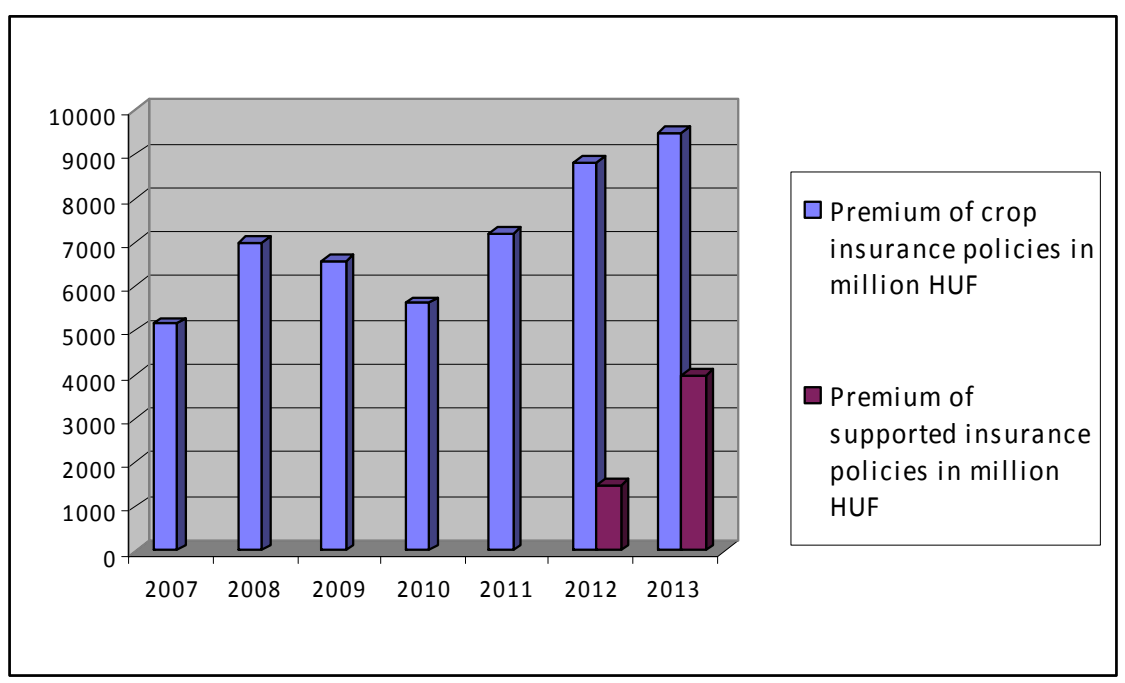

Figure 4. The amount of market insurance premiums and the premium supports of the second pillar of the risk management system between 2007 and 2013, Source: MVH

The reform succeeded; the membership of both pillars increased, like the number and premium of insurance policies and the sources of the mitigation fund. In addition the precision of the mitigation payments increased; consequently only the real crop losses were mitigated. The procedure was still based on manual operation and the cooperation among the institutions had to improve (Figure 5).

From 2012 the operation of the mitigation information system has improved significantly: the following professional state organizations GDWM (Basic data services of inland water), HMS (Basic meteorological data services), IGCRS (Remote sensing data services), RIAE (Professional monitoring and analysis of the agricultural production and market) provided accurate continuous service for the damage determination.

It meant further progress that the insurance companies informed ARDA electronically (via email) about the existence of an insurance contract after it was signed with a producer. Insurance certificates for mitigations were also forwarded electronically to ARDA. A major step forward was that the producers could login to the state mitigation system parallel with the generally used Single Application system when filling their claim electronically. In spite of the automated agricultural damage assessment the claim reporting system remained unchanged. The procedure of damage notification, the damage claim notification, and the official damage determination remained "paperbased", with all its disadvantages. There was no central database, and there was no detailed integrated information about the farmers' production, the damages and the interrelation between the damages and the weather conditions. Thus, there were only estimations whether the system was working properly and which participants were the winners and losers of the system. 


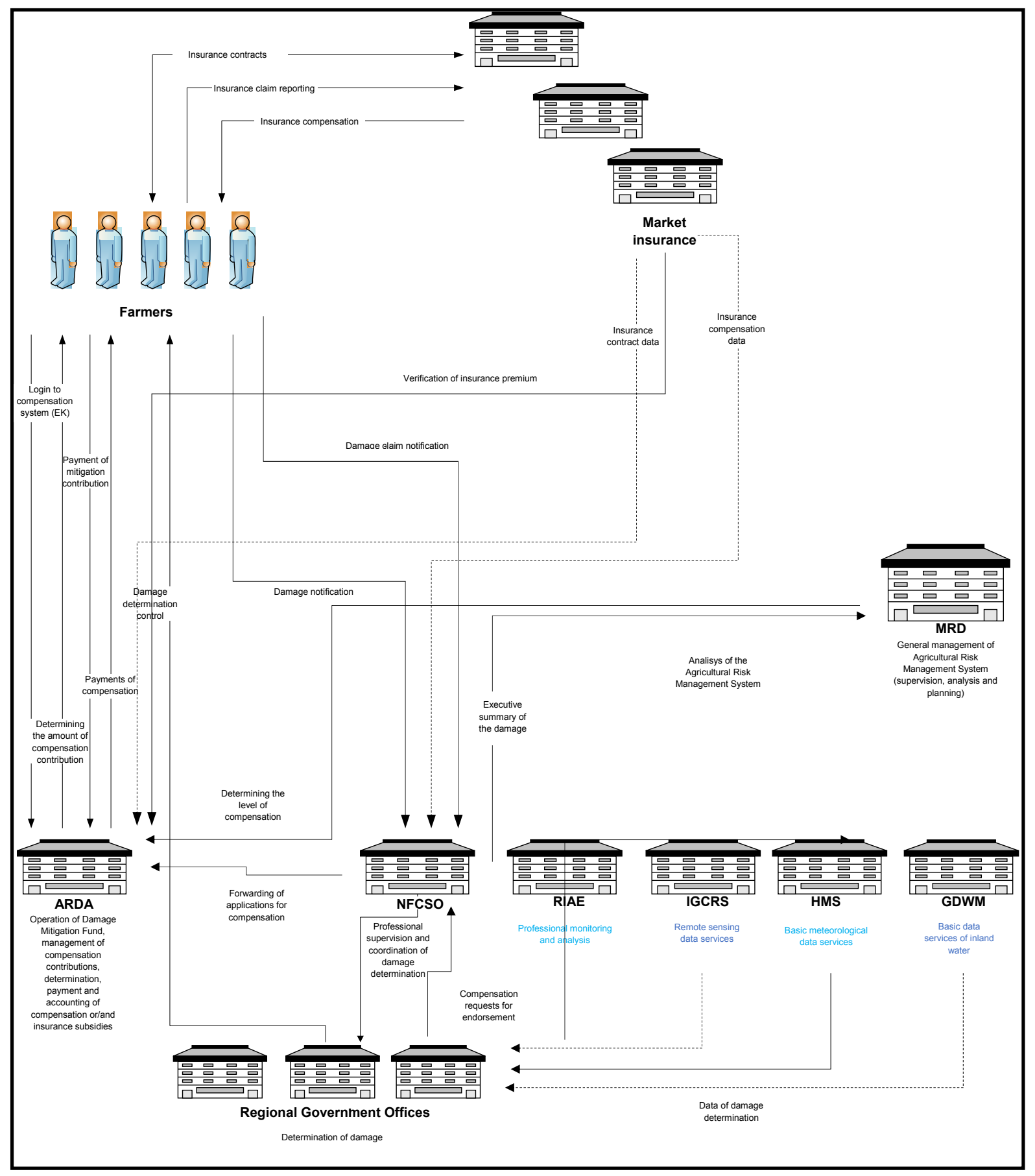

Figure 5. Flow chart of the Coordinated Agricultural Risk Management System (Blue text shows the new activities which support the claim adjustment of the meteorological damages.), Source: $M V H$

\section{The operation of the Integrated Agricultural Risk Management System}

The above mentioned Agricultural Risk Management Act described an intensive communication among the different state institutes, the farmers and the insurance companies. Naturally there was significant cooperation among the participants of the system, but the communication was paper-based, without central database, which was characterized by many errors delays and high expenses.

A further improvement could be the introduction of the Integrated Agricultural Risk Management System which could connect the members of the risk management system by a new central information system. The Hungarian agricultural administration tendered to realize this project and won in the Electronic Government Operation Program financed by the European Union. 
The project numbered by EKOP 1.1.12-2012-2013-0001 got the name Complex Agricultural Risk Management System. The leader of the consortium has been ARDA which is the paying agency of the Hungarian agricultural sector.

The members of the consortium are MRD, GDWM, HMS, IGCRS and the NFCSO (responsible for damage assessment) and RIAE (responsible for research and development of the agricultural risk management). The consortium cooperates with the Hungarian Chamber of Agriculture (HCA) and RGO, their task is the site inspection of crop losses claimed by the farmers.

The time scale of the project is from July 1, 2013 to June 30, 2014. The financial source is 1.250 billion HUF, the state subsidization intensity is 100 percent.

The project is aiming to develop a central information system operated by ARDA. This system will be linked to the Agricultural Parcel Identification System (operating in ARDA), and all the information sent by the members and farmers will be linked to the same parcel database. The common ground of information will be the geo-informatics, and the information linked to the same parcel will support the official control of crop loss assessment, damage mitigation and compensation paid by insurances and paid by NDMF (Figure 6). 


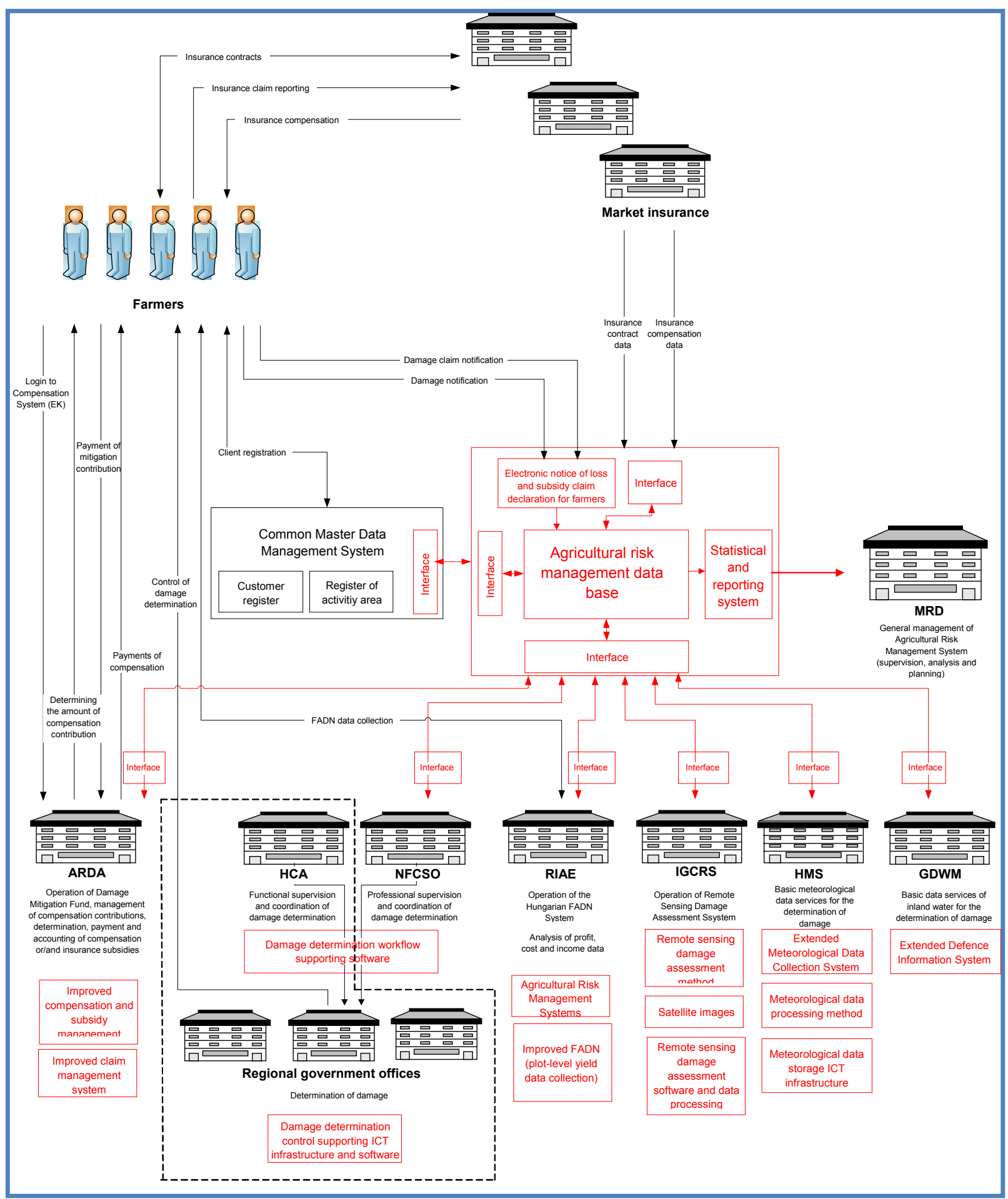

Figure 6. Flow chart of the Integrated Agricultural Risk Management System (Red text shows the new activities and databases of the claim adjustment), Source: $M V H$

The most important elements of the project are:

- Electronic notice of loss and claim declaration for farmers (contact between farmers and ARDA)

- Electronic insurance premium subsidy claim for farmers/insurance companies (contact between farmers/insurance companies and ARDA) 
- Electronic notice of official decisions about the damage mitigation and the insurance premium subsidy (contact between ARDA and farmers)

- Business intelligence unit for the members of the consortium (contact among ARDA and other partners, especially between ARDA and the ministry)

- Integrated electronic claim adjustment support with meteorological, remote sensing and water management indices (contact among GDWM, IGCRS, HMS and ARDA, as well as among ARDA and NFCSO and the regional offices)

- Claim adjustment substitution by agro meteorological crop estimating models and by remote sensing maps about inland water (contact between IGCRS and ARDA, as well as among ARDA and NFCSO)

- Site inspection verification by electronic and GIS technologies (contact among NFCSO and the RGO and HCA officers)

After the successful implementation of the project on June 30, 2014, the following results can be expected:

- Significant increase in the number of functional areas covered by informatics (target: complete electronic coverage, only special cases are handled manually)

- Reduction of the required human administration (target: $50 \%$ reduction in administration-time spent)

- Objectively documented, flexible system using retrospective data built up over several years,

- Strengthening the electronic and data cooperation among the professional and state organizations

Accurate assessment of the real improvements can be and will be checked at least after one year of operation in November 2015.

\section{Conclusion}

The Integrated Agricultural Risk Management project will result in three important changes in the process of risk management in Hungary. Firstly, the administration burden and administrative costs of the farmers, and institutions will decrease. Secondly, the precision of the mitigation system will increase - only the real losses will be compensated. Thirdly, a new database will be created by the Complex Agricultural Risk Management System, which can be the basis of the data needs of the future scientific research in fields of climate change, risk management, water management, irrigation, as well as the data needs of the state regulations.

\section{References}

Antón, J., Kimura, S. and Martini, R. 2011. Risk Management in Agriculture in Canada. OECD Food, Agriculture and Fisheries Papers, No. 40, Paris: OECD Publishing.

de Bruin, K., Dellink, R. and Agrawala, S. 2009. Economic Aspects of Adaptation to Climate Change: Integrated Assessment Modelling of Adaptation Costs and Benefits, OECD Environment Working Papers, No. 6, Paris: OECD.

Kemény G., Varga T., Fogarasi J., Nemes A. 2013. The effects of weather risks on micro-regional agricultural insurance premiums in Hungary In: Studies in Agricultural Economics 2013/115/1 pp. 8-15.

Kemény G., Varga T., Fogarasi J., Kovács G., Tóth O. 2011. A hazai mezőgazdasági biztositási rendszer problémái és továbbfejlesztésének lehetöségei [Problems and Further Development Possibilities of the Hungarian Agricultural Insurance System] Budapest, Agrárgazdasági Kutató Intézet. 124 p.

MABISZ. 2013. Statistics of Hungarian agricultural insurances. Magyar Biztosítók Szövetsége [Association of Hungarian Insurance Companies] 
Mahul, O. and Stutley, C.J. 2010. Government Support to Agricultural Insurance: Challenges and Opportunities for Developing Countries. Washington: World Bank.

MVH. 2013. Compensation claims and mitigation benefits paid for farmers from the NAR in Hungary. Mezőgazdasági és Vidékfejlesztési Hivatal [Agricultural and Rural Development Agency]

OECD (2009): Managing risk in agriculture: A holistic approach. Paris: OECD.

Smith, V.H. and Glauber, J.W. 2012. Agricultural Insurance in Developing Countries: Where Have We Been and Where Are We Going? Applied Economic Perspectives and Policy 34(3), 363-390.

Székely and Pálinkás 2009. Agricultural Risk Management in the European Union and in the USA, Studies in Agricultural Economics 109, 55-72. 